\title{
GENDER AND DIGITAL PIRACY: \\ Examining Determinants of Attitude toward Digital Piracy among Youths in an Emerging Market
}

\begin{abstract}
Digital piracy is rampant in developing countries, including Indonesia. Each year, it has caused billions of dollars of loss to many industries, such as software, video game, film, and music industries. The present study aims to examine the determinants of attitude towards digital piracy and to explore whether gender matters in explaining the attitude. A convenience sample of 223 university students in Daerah Istimewa Yogyakarta (DIY), Indonesia, participated in the research. The results show that males have a more positive attitude towards digital piracy than females. The determinants of attitude towards digital piracy among female consumers are affective beliefs, perceived importance of digital piracy issue, and Machiavellianism, while the predictors for the male counterparts include affective beliefs, perceived importance of digital piracy issue, and moral judgment.
\end{abstract}

Keywords: Digital Piracy, Gender, Attitude, Theory of Planned Behavior, Indonesia.

"Controlling software piracy is like squeezing a balloon: Holding one part tightly simply results in the balloon expanding in another direction" (Moores and Esichaikul, 2010, p. 5)

\section{Introduction}

Digital piracy has been a major concern all over the world (Cronan and Rafee, 2008; Hennig-Thurau, et al., 2007; Phau and Liang, 2012; Yoon, 2011). The term 'digital piracy’ refers to the illegal copying, sharing, buying, and/or downloading of copyrighted software, audio products, video, books, and pictures. It is a prevalent and serious problem in Indonesia (Abisheka, 2003; Asrianti, 2011). Despite many efforts to combat all forms of piracy in Indonesia, the results have been deemed ineffective. For instance, in their survey of piracy rates in 33 countries, Business Software Alliance (BSA, 2012b) found that Indonesia has one of the highest rates in the world, where $86 \%$ of software in Indonesia is pirated, resulting in a loss of US\$1.46 billion per year to the original PC software manufacturers.

Furthermore, online access has grown significantly in Indonesia with 62 million Internet users in 2013 (up from 55 million in 2012), 282 million mobile phone subscribers 
(more than 100\% penetration), and 3 million fixed broadband subscriptions in 2013 (IIPA, 2014). These figures may indicate opportunities for distributing copyright materials, but in reality online and mobile piracy have grown faster (IIPA, 2014). While in the past, many Indonesians were willing to buy original cassettes or CDs, now most of them prefer to download their favourite music or buy pirated CDs and listen to them via their smartphones, MP3 players, or tablets (Eri, 2012; IIPA, 2014; Moestafa, 2003).

Digital piracy can be viewed as an example of end-user piracy (Bender and Wang, 2009), where individuals can obtain digital materials (e.g., MP3s, movies, software, pictures, e-books, and games) for their own personal enjoyment without physical transactions. They further suggest that end-user piracy may be more difficult to detect than commercial piracy. However, most of the research on digital piracy has focused on examining the reasons why manufacturers committed piracy (the supply side); whereas, few studies have investigated the factors influencing consumers to buy, download, share, and/or copy illegal copyrighted materials (the demand side) (Penz and Stöttinger, 2005).

Some studies revealed that closing down shops or online shops (Moore and Esichaikul, 2010) and blocking illegal downloading sites (Purwanto, 2012) have failed to stop people from continuing their pirating behaviour. While one site is closed down, new sites will emerge (IIPA, 2014; Purwanto, 2012). Increased availability and sophistication of copyright protection and digital rights management technologies, also, have been shown to be ineffective in combating digital piracy (Sundararajan, 2004). Instead of relying solely on such actions, Al-Rafee and Cronan (2006) argue that understanding what might influence individuals to pirate would be a more effective path. Some studies also suggest that increasing individuals' awareness of potential severity and certainty of punishment (Yoon, 2011) or actively socializing anti-piracy campaigns (Moores and Esichaikul, 2009) may be more effective in lessening individual attitudes toward digital piracy, which may, in turn, lead to 
lower intention to pirate and actual pirating behaviours. Nevertheless, while several aspects of counterfeiting have been investigated in the USA (e.g., Al-Rafee and Cronan, 2006; Chaudhry and Stumpf, 2011; Cronan and Al-Rafee, 2008; Lysonski and Durvasula, 2008), Germany (Hennig-Thurau, et al., 2007), the UK (Cockrill and Goode, 2012), the People Republic of China (Phau and Teah, 2009; Wang, Zhang, Zang, and Ouyang, 2005; Yoon, 2011), Brazil

(de Matos, Ituassu, and Rossi, 2007), and Israel (Shoham, Ruvio, and Davidow, 2008), a systematic study in the Indonesian context, the fourth most populous country, is lacking. Such study is important since digital piracy "poses a more serious problem in developing countries than in developed countries” (Aleassa, et al., 2011, p. 663).

The current study aims to examine determinants of consumer attitude toward digital piracy among youths (i.e. university students) in Indonesia. Specifically, it explores whether gender matters in explaining the attitude towards digital piracy. Studies on unethical behavior have produced somewhat mixed findings, where some studies concluded that females tend to be more ethical than males, while other studies found no significant gender differences (O’Fallon and Butterfield, 2005; McCabe, et al., 2006).

\section{Literature Review and Hypotheses Development}

Digital Piracy. The advancement of information and communication technology (e.g., the internet, computer, mobile phone technology) has given way to a new type of theft, digital piracy (Al-Rafee and Cronan, 2006; Hennig-Thurau, et al., 2007; Phau and Liang, 2012; Yoon, 2011). Digital piracy refers to the illegal copying, buying, sharing, and/or downloading of copyrighted software (programs, games, applications); audio products (music, recorded speech, tutorials, conversations); video (movies, video clips, recorded concerts, television shows); books (e-books, magazines, journal articles); and pictures (images and photos). It covers hard goods piracy ("the illegal reproduction of physical products such as music CDs, 
DVDs videos or softwares”) and "the diffusion of digitalized cultural goods over the Internet using, for example, file-sharing communities” (Dejean, 2009, p. 329). Digital products are often characterized as information goods that are expensive to produce but cheap to reproduce (Sinha and Mandel, 2008). Thus, such products are susceptible to piracy.

Attitude towards Digital Piracy. Attitude is one of the major components of the theory of reasoned action (Fishbein and Ajzen, 1975; Ajzen and Fishbein, 1980) as well as its extension, the theory of planned behaviour (Ajzen, 2005). Attitude towards digital piracy refers to an individual's favourable or unfavourable evaluation regarding pirating any digital products (Ajzen, 2005; Yoon, 2011). Many previous empirical studies have validated the significant impact of attitude on intention to pirate (e.g., Chang, 1998; Cronan and Al-Rafee, 2008; Morton and Koufteros, 2008; Wang, et al., 2005; Yoon, 2011). Ajzen (2001) argue that the ability of attitude to predict behavioural intention and behaviour has made it one of the main focuses of theory and research in behavioural studies. While many studies investigate attitude towards digital piracy as an independent variable, there is a paucity of research examining determinants of attitude towards digital piracy (i.e., attitude as a dependent variable) (Al-Rafee and Cronan, 2006). Since studies reveal that attitude toward digital piracy can be changed through persuasion and other means (Cronan and Al-Rafee, 2008), it becomes an important topic for a comprehensive study. Figure 1 provides a conceptual framework of determinants of attitude towards digital piracy (adapted from Al-Rafee and Cronan, 2006).

\section{Insert Figure 1 about Here}

Gender and Attitude towards Digital Piracy. Gender is one of the most heavily investigated variables in business ethics literature (Dalton and Ortegren, 2011; McCabe, et al., 2006; Robin and Babin, 1997), since it has been identified as an important factor affecting ethical reasoning (Ameen et al., 1996; Jones and Gautchi, 1988), including consumer attitude towards digital piracy (Al-Rafee and Cronan, 2006). Gender socialization theory suggests that 
differences in socialization contribute to different perceptions of ethical issues between males and females (Gilligan, 1987, cited in Moores and Chang, 2006). Males are socialized to emphasize the principles of fairness and equity, while females are socialized to focus on maintaining relationships and empathizing with others (Dalton and Ortegren, 2011; Lee, 2009; Mason and Mudrack, 1996; Moores and Chang, 2006). However, the findings tend to be conflicting (Ford and Richardson, 1994; Loe et al., 2000; O’Fallon and Butterfield, 2005; McCabe, et al., 2006). A group of studies found that females display less favourable attitudes towards piracy, including digital piracy (e.g., Beu, et al., 2003; Bhattacharjee, et al., 2003; Borkowski and Ugras, 1998; Cohen, et al., 2001; Ergeneli and Arikan, 2002; Franke, et al., 1997; Gopal and Sanders, 1997, 1998; Kwong, et al., 2003), while another group reported insignificant differences between genders (e.g., Al-Rafee and Cronan, 2006; Fleischman and Valentine, 2003; Gan and Koh, 2006; Hsieh and Lee, 2012; Kini, et al., 2000; Moores and Chang, 2006; Paradice and Dejoie, 1991; Robertson, et al., 2012; Robin and Babin, 1997; Roxas and Stoneback, 2004). The inconsistency between such findings is worth further investigation. Therefore, $\mathrm{H}_{1}$ can be hypothesized as follows.

H1. Males will have a more positive attitude towards digital piracy than females.

Cognitive Beliefs. The theory of planned behaviour postulates that attitude development is determined by the behavioural beliefs of an individual (Ajzen, 2005). According to Ajzen et al. (2011), a belief is basic information that eventually determines behaviour, which is assumed to guide intention of an individual. In the present study's context, cognitive beliefs represent the individual's opinion about digital piracy behaviour (in terms of outcomes of pirating digital material). Al-Rafee and Cronan (2006) revealed that cognitive beliefs have a significant and positive effect on the individual's attitude towards digital piracy. Hence, this reasoning leads to the following hypothesis. 
H2. Cognitive beliefs have a positive impact on attitude toward digital piracy.

Affective Beliefs. Several studies indicated that affective and cognitive beliefs are two different constructs influencing attitude (e.g., Bodur, Brinberg and Coupey, 2000; Trafimow and Sheeran, 1998). Affective beliefs refer to emotions that engendered by the prospect of performing behaviour (Breckler and Wiggins, 1989). Bodur, Brinberg and Coupey (2000), for instance, found that affective beliefs have a direct effect on attitude. Consequently, the following hypothesis can be stated.

H3. Affective beliefs have a positive impact on attitude towards digital piracy.

Perceived Importance of Digital Piracy Issue. Robin and Reidenbach (1996) state that perceived importance of an ethical issue affects ethical judgment. They suggest that when people think that an ethical issue is important, they are less likely to commit an unethical behaviour. Singhapakdi (1999) found that marketers who perceived ethical and social responsibility to be important tended to be more ethical than their counterparts. Studies both in the U.S. and Thailand suggest that there is a positive relationship between perceptions on the importance of ethics and ethical intention (Singhapakdi et al., 2007; Singhapakdi et al., 1995). Therefore, the perceived importance of digital piracy issue is negatively associated with attitude toward pirating digital material (Al-Rafee and Cronan, 2006). This proposition was supported in Al-Rafee and Cronan's (2006) study of digital piracy. Therefore, the following hypothesis can be proposed as follows.

H4. Perceived importance of digital piracy issue has a negative effect on attitude towards digital piracy.

Moral Judgment. Moral judgment is one of the four components of cognitive developmental psychology, which was developed by Lawrence Kohlberg (Jagger, 2011). Banerjee, Cronan and Jones (1998) defined moral judgment as the way a person reasons when 
faced with an ethical situation. Kohlberg's theory, then, addressed the nature of the reasoning process behind an individual's judgment of whether or not behaviour is deemed to be ethical (Bay and Greenberg, 2001). It was suggested that an individual with a high moral judgment will consider his/her actions and compare them with the goodness of the society (Al-Rafee and Cronan, 2006; Kohlberg, 1969). Moral judgment has been used to predict ethical judgment and attitude in the ethics research (Banerjee, Cronan and Jones, 1998; Schepers, 2003; Vitell, Rallapalli and Singhapakdi, 1993). Logsdon, Thompson and Reid (1994), for instance, found that pirating illegal software is perceived as an issue of low moral judgment. Lysonski and Durvasula (2008) also suggested that consumers will have a positive attitude toward digital piracy and a high intention to pirate if they believe that the action is not ethically wrong. Therefore, $\mathrm{H}_{5}$ can be formulated as follows.

H5. Moral judgment has a negative impact on attitude towards digital piracy.

Machiavellianism. In his book, The Prince, published in 1513, Niccolo Machiavelli educated new leaders to the harsh realities of leading a nation. ${ }^{1}$ He identified negative character traits that include "manipulation, cunning, duplicity and bad faith” in acquiring and maintaining power (Wakefield, 2008, p. 115). In later development, the term Machiavellian has been used to refer to a person who "manipulates others for personal gain" (Wastell and Booth, 2003, p. 730). A Machiavellian individual is described as being less emotionally involved with others, having few interpersonal relationships, and more likely to reject ethical norms in order to accomplish personal goals (Wakefield, 2008). Prior studies suggest that individuals with high Machiavellianism show less sympathy for the losses of artists and music companies (Sinha and Mandel, 2008); tend to be more deceitful (McLaughlin, 1970); less moral, and more manipulative (Long, 1976). Consequently, individuals with high

We thank an anonymous reviewer for clarifying this point. 
Machiavellianism will be less concerned about unethical behaviour. Thus, they will have a more positive (favourable) attitude towards digital piracy. Support for this hypothesis was found in the finding by Al-Rafee and Cronan (2006), that Machiavellianism had a significant and positive influence on attitude towards pirating digital material. In line with this, $\mathrm{H}_{6}$ is postulated as follows:

H6. Machiavellianism has a positive impact on attitude towards digital piracy.

\section{Methodology}

Research Context. Indonesia was chosen as the research setting for the current study. The fourth most populous country in the world is one of ten countries in the 'Priority Watch List' of the intellectual property rights cases (USTR, 2014). A survey by Business Software Alliance (BSA) Indonesia on 518 computer users in Indonesia found that more than half of the respondents (59 percent) admitted to have acquired pirated software (BSA, 2012a; 2012c). The software piracy rate in Indonesia (86\%) is one of the worst in the world (BSA, 2012b). Moreover, the Indonesian music industry suffers more than its software industry, where the overall loss is about 95 percent of the market due to piracy of all kinds (IIPA, 2012). According to the International Federation of Phonographic Industry (IFPI) (cited in Fit and Doe, 2012), there were about seventy websites that provided free access to download music and songs. IIPA (2012) also identified more than 260 other websites known to provide links to unauthorized Indonesian music files (such as 4shared.com, mediafire.com and ziddu.com). The lack of law enforcement and the growing usage and access to the Internet (about 62 million users or about 25 percent of the total population in December 2013; IIPA, 2014) has contributed to the rampant digital piracy in the country.

Sample. Self-administered questionnaires were distributed to a convenience sample of 282 students in four major universities in the Daerah Istimewa Yogyakarta (DIY) province, 
Indonesia. Students were chosen as the samples for two main reasons. First, a significantly high proportion of students have shown to engage in digital piracy (e.g., Aleassa, Pearson and McClurg, 2011; Gopal and Sanders, 2000; Levin, Dato-on and Rhee, 2004; Lysonski and Durvasula, 2008; Phau and Liang, 2012; Sims and Cheng, 1996; Yoon, 2011). Cheng, Sims and Teegen (1997) suggest that the digital piracy issue is more prevalent in academia than in business, where universities were believed to represent an ideal proliferation place for piracy. Similarly, Wade (2004) argued that university students made up a large portion of illegal downloading, as a result of high-speed network connections and having ample time to engage in such pirating efforts.

Second, student samples have been considered as adequate and representative of business community and have been used in ethics literature to investigate software and online music piracy (Al-Rafee and Cronan, 2006; Borkowski and Ugras, 1999; Morton and Koufteros, 2008; Wagner and Sanders, 2001). Student samples have been assumed to be suitable surrogates for business managers and decision makers, especially in the ethical decision-making process study (Al-Rafee and Cronan, 2006; Cheng, Sims and Teegen, 1997; Riemenschneider, Leonard and Manly, 2012).

Daerah Istimewa Yogyakarta (DIY) was selected as the site for participant selection because it is well-known as 'a city of students' (kota pelajar). During the period of 20102011, there were 122 colleges (10 state universities and 112 private colleges) registered in the region with 233,215 students or 6.74 percent of its 3.4 million population (BPS, 2011).

Measures. All the scales used in the present study were adopted from established measures. The original items were translated into Bahasa Indonesia and back translated to ensure consistency. Attitude towards digital piracy was measured using four items (i.e., favourable/unfavourable, harmful/beneficial, foolish/wise and good/bad) as responses to a 
question “Overall, my attitude toward digital piracy is” (Al-Rafee and Cronan, 2006; Yoon, 2011).

Cognitive beliefs were measured using 14 items, consisting of seven pairs measuring individuals' beliefs and the importance of the beliefs (evaluations) (Al-Rafee and Cronan, 2006). For instance, "I believe that digital material is overpriced" was paired with "How important is the fact that digital material is overpriced?” Seven point Likert scales were used, where "strongly agree - strongly disagree" was for the beliefs and "very important - not important at all" for the evaluations (importance of the beliefs).

In measuring affective beliefs, respondents were asked to express how they felt when pirating digital material. Nine items were used for the measurement, where six items were related to positive affective beliefs, while the rest was associated with negative affective beliefs (Al-Rafee and Cronan, 2006). The questions include "I feel (elated/excited/active/happy/pleased/satisfied) when I pirate digital material” (positive affective beliefs) and "I feel (anxious/fearful/nervous) when I pirate digital material" (negative affective beliefs). All questions used a seven-point Likert scale, ranging from "not at all” to "very much so".

Perceived importance was measured using four items, i.e. "To me, the issue of digital piracy is an extremely important issue/unimportant issue, highly significant issue/insignificant issue, issue is considerable concern/issue is of no concern, and fundamental issue/trivial issue (Al-Rafee and Cronan, 2006).

Moral judgment was measured using the short-form of the Defining Issue Test (DIT) (Rest, 1986), which consists of three moral/ethical dilemma stories, i.e. Escaped Prisoner, Heinz and the Drug, and the Doctor's Dilemma. Each story has three different sections (see Table 1). In the first section, after the respondents read the story, they were asked to indicate their preferred solution to the dilemma (for example, in the Escaped Prisoner story, whether 
Mrs. Jones should report Mr. Thompson to the police, should not report him, or even cannot decide). In the second section, as suggested by Rest (1986), respondents were required to rate each statement for its importance in making their judgment by using a five-point Likert scale (i.e., "great”, "much”, “some”, "little”, and none”). During a pre-test of the research instruments, it was found that many respondents thought the scale was confusing. Thus, it was decided to modify the scale into " $100 \%, 75 \%, 50 \%, 25 \%$, and $0 \%$ " (where $100 \%$ indicates great importance and $0 \%$ means no importance). In the third section, respondents were asked to rank the four most important questions in the second section. Each dilemma story has its own code for each statement, which refers to certain stages of the moral judgment. The moral judgment is represented by P-score or 'principled moral thinking' or also known as 'postconventional score' (Doyle, Hughes and Summers, 2009). The P-score represents the percentage of time respondents make decisions based on the overall high moral judgment stages (stage 5 and 6 of Kohlberg's six stages of moral development) (Al-Rafee and Cronan, 2006). The P-score is calculated by assigning points to the four most important statements that related to the Stages 5 and 6 (postconventional level) of the DIT (Ishida, 2006). The specific calculation of P-score was based on the DIT Manual (Rest, 1986).

It is important to note that some modifications were undertaken in the present study to adapt to the Indonesian context. For instance, the character names of each story were changed into Indonesian names (i.e., Mr. Thompson, Mrs. Jones, and Heinz became Sule, Jupe, and Tukul, respectively). One of the questions in the Heinz and the Drug story says "Is Heinz willing to risk getting shot as a burglar or going to jail for the chance that stealing the drug might help?” 'Getting shot' seems not relevant to the Indonesia context, while 'being beaten by masses' seems to be more suitable. Thus, the question was changed into: “Is Tukul willing to risk being beaten by masses or caught by the police for the chance that stealing the drug might help his wife?” 


\section{Insert Table 1 about Here}

Finally, Machiavellianism was assessed with the MACH IV scale (Christie and Geis, 1970), consisting of 20 items on a seven-point Likert scale, ranging from 1 (Strongly Disagree) to 7 (Strongly Agree). The items include questions like 'honesty is the best policy in all cases', 'it is possible to be good in all respects', and 'there is no excuse for lying to someone else'. In addition, several demographic profile questions were asked, such as gender, age, marital status, religion, current education level, and study field.

\section{Findings}

From 282 distributed questionnaires, only 223 of them were returned and usable (a response rate of 79.08 percent). The profiles of the respondents are summarized in Table 2. It shows that the number of female respondents is almost twice that of males. The majority of the respondents were aged between 18-20 years old (49.8 percent). Almost all of the respondents were single (97.3 percent) and still studying at a university (94.2 percent). About half of the respondents (48.4 percent) were studying at the Faculty of Economics (i.e., majoring in Management and Accounting).

\section{Insert Table 2 about Here}

Using Cronbach's alpha of 0.70 as the cut-off rate (Nunnally, 1978), it can be concluded that all multiple-item measures for the present study are reliable. The Cronbach's alphas for the main constructs are as follows: attitude towards digital piracy ( 4 items, $\alpha=$ 0.830); Machiavellianism (13 items, $\alpha=0.698$ ); cognitive beliefs (four items, $\alpha=0.751$ ); affective beliefs (nine items, $\alpha=0.935$ ); and perceived importance (four items, $\alpha=0.901$ ). It is important to note that some items are reversed items, so they were coded accordingly. Meanwhile, moral judgment was measured using P-score index and it does not require a reliability test. Table 3 summarizes the reliability and correlation results. 


\section{Insert Table 3 about Here}

$\mathrm{H}_{1}$ proposes that males will have a more positive attitude towards digital piracy than females. An independent sample t-test result shows that male respondents had a significantly more favourable attitude towards digital piracy than female counterparts (mean scores of 3.678 versus $3.230 ; \rho=0.026$ ) (see Table 4). Therefore, $H_{1}$ was supported.

\section{Insert Table 4 about Here}

Two ordinary least squares (OLS) regression analyses were used to examine determinants of attitude towards digital piracy in male and female samples. Table 5 presents the summary of the results. The findings indicate that about 36.4 percent of the variances in attitude towards digital piracy among female respondents can be explained by the variation in cognitive beliefs, affective beliefs, perceived importance, moral judgment, and Machiavellianism. The Adjusted $\mathrm{R}^{2}$ for the male sample was higher (0.475).

\section{Insert Table 5 about Here}

Cognitive beliefs were expected to be one of the predictors of attitude towards digital piracy. A positive effect was hypothesized in $\mathrm{H}_{2}$. However, the OLS regression results indicate that the effects were not statistically significant $(\beta=-0.010, \rho=0.892$ for female sample; $\beta=-0.118, \rho=0.221$ for male sample). It suggests that cognitive beliefs about digital piracy (i.e., the chance of getting caught while pirating digital products, time and money saving, the convenience of pirating, and so forth) do not have a significant influence on attitude towards digital piracy. Consequently, $\mathrm{H}_{2}$ was not supported.

As predicted by $\mathrm{H}_{3}$, affective beliefs were found to have a significant positive effect on attitude towards digital piracy among both samples $(\beta=0.361, \rho=0.000$ for female sample; $\beta=0.368, \rho=0.001$ for male sample). It indicates that individuals who felt positive (i.e. happy, excited, and pleased) when pirating digital material had a more favourable attitude towards digital piracy. As a result, $\mathrm{H}_{3}$ was supported. 
Similarly, a significant negative effect of perceived importance of digital piracy issue on attitude towards pirating digital products was found $(\beta=-0.269, \rho=0.001$ for female sample; $\beta=-0.225, \rho=0.021$ for male sample). It suggests that the more important the issue of digital piracy as perceived by an individual, the less favourable his/her attitude towards pirating digital material. Hence, $\mathrm{H}_{4}$ was supported.

Support was found for the negative impact of moral judgment (as measured by Pscore) on consumer attitude towards digital piracy among the male respondents $(\beta=-0.223, \rho$ $=0.013)$. However, the effect was insignificant in the female sample $(\beta=0.035, \rho=0.600)$. As a result, $\mathrm{H}_{5}$ was partially supported.

Machiavellianism was expected to have a positive impact on attitude towards digital piracy $\left(\mathrm{H}_{6}\right)$. A partial support was found to this hypothesis, i.e. among the female sample. The higher the Machiavellianism level, the higher (more favourable) the attitude towards digital piracy, and vice versa $(\beta=0.140, \rho=0.045)$. It shows that high Machiavellianism individuals are not concerned so much about unethical behaviour, including pirating digital material. However, the result was insignificant in the male sample $(\beta=0.127, \rho=0.190)$. Thus, $\mathrm{H}_{6}$ was partially supported.

\section{Discussion and Implications}

Empirical studies have found support for the positive effect of attitude toward digital piracy on an individual's intention to pirate digital material (e.g., Cronan and Rafee, 2008; Morton and Koufteros, 2008; Peace, Galletta, and Thong, 2003; Phau and Liang, 2012; Shoham, Ruvio, and Davidow, 2008; Yoon, 2011). Although many studies have used attitude as an antecedent, it is argued that an investigation of digital piracy using attitude as a consequence is equally important (Al-Rafee and Cronan, 2006). 
The current study aimed to examine the antecedents of Indonesian young consumers' attitude towards digital piracy and to explore whether gender matters in explaining the attitude towards digital piracy. The results show that males have more positive attitude towards digital piracy than females. It supports gender socialization theory, which suggests that females and males have different perceptions and attitudes towards ethical issues due to their differences in socialization (Gilligan, 1987, cited in Moores and Chang, 2006). In terms of the antecedents of attitude towards digital piracy, the determinants among the female sample are affective beliefs, perceived importance of digital piracy issue, and Machiavellianism. Meanwhile, the predictors for the male sample include affective beliefs, perceived importance of digital piracy issue, and moral judgment.

It is found that how individuals feel when pirating digital material significantly affects their attitude towards digital piracy. If they feel happy, excited or satisfied, they are likely to have a more favourable attitude towards pirating digital material; whereas, if they feel distress or nervous, they may have a more negative attitude towards digital piracy. Efforts to reduce the piracy rate in Indonesia could be directed at creating a negative feeling towards digital piracy (e.g., being afraid of getting caught, being punished for the illegal activity, being attacked by computer viruses, having a guilty feeling for breaking the law, and so forth) and reducing the positive affective beliefs of pirating digital material (e.g., severe penalty that can negate the time and money saving benefits of digital piracy). In this context, consistent and strong law enforcement in protecting intellectual properties is required. The law enforcement has to apply to manufacturers, distributors, sellers, and buyers as well. When implemented, this will contribute to the development of negative attitudes toward digital piracy among Indonesians, which in turn will reduce their intention to buy, copy, share, and/or download copyrighted materials illegally. 
To fight counterfeit, it is important to raise the perceived importance of digital piracy issue. The more important the issue of digital piracy, the less favourable an individual's attitude towards the piracy. It suggests that socialization and education programs to increase public's awareness of the detrimental effects of digital piracy are both crucial and effective. BSA (2011), for instance, reported that many Indonesians do not see piracy as a crime nor as unethical. Many PC (personal computer) users were lacking in understanding that software downloaded from a peer-to-peer network is often illegal and that buying a single program license for multiple computers is piracy. Furthermore, IIPA (2012) also suggested communicating the benefits of fighting piracy to the Indonesian economy as a means of reducing digital piracy. In addition, universities have to be the role leaders in using and buying only authorized digital products, including software, movies, e-books, and other materials. Government needs to raise the importance and seriousness of copyright protection, including the criminalization of violators of software copyright (The Indonesian Copyright Law Number 19, Year 2002 Article 72 No. 3).

A partial support was found for moral judgments as a negative antecedent of attitude towards digital piracy. However, the average P-scores for the female and male samples were 25.125 and 23.026, consecutively (in a range of 0-95), an indication of low moral judgment among the respondents (Rest, 1986). This may suggest that digital piracy is perceived as an acceptable practice in Indonesia. Young Indonesians did not consider it as morally wrong.

Machiavellianism was also partially supported as a positive predictor of attitude towards digital piracy. A high Machiavellianism person tends to have a more favourable attitude towards pirating digital material than a low Machiavellianism individual. Such an individual does not care about the risks or the punishments he/she will get for pirating digital material as long as he/she could get what he/she wants. Previous studies have suggested that 
high Machiavellianism can be related to the cunning and duplicity proneness of an individual (e.g., Hartmaan and Maas, 2010; Schepers, 2003; Wakefield, 2008).

In the present study, cognitive beliefs failed to predict attitude towards digital piracy. This finding suggests that many young Indonesians are unconcerned with whether or not the quality of pirated digital material is far poorer than the originals. Indonesian youth, also, are unconcerned with whether the software developers suffer a loss when the products are being pirated.

However, digital piracy is a very difficult and complex issue to overcome. There is no instant solution to reduce or fight the problem. Nevertheless, the findings of this study may assist policy makers and managers in their efforts to fight digital piracy in Indonesia.

\section{Limitations and Future Research}

Despite the potential contributions of the current study, there are some limitations worth noting. First, the use of a convenience sample of students derived from several universities in one city in Indonesia may limit the generalizability of the findings. Future research may use a more diverse sample by obtaining data from broader geographic and demographic categories; i.e., more cities across geographic and demographic variables; e.g., different income levels, in addition to non-student samples. For instance, one survey in Indonesia revealed that low-income people tend to commit digital piracy because they do not have enough money to buy the originals (Eri, 2012).

Second, gender is a complex social-psychological construct (McCabe, et al., 2006). Consequently, treating it as a dichotomous variable (i.e. biological sex) may limit the value of the research findings (McCabe, et al., 2006). Third, the present study did not control for social desirability response bias. Dalton and Ortegren (2011) suggest that social desirability mediates the relationship between gender and ethical decision-making. Further studies are 
needed to clarify the values of using multidimensional measure of gender and the controlling for social desirability response bias in digital piracy research.

Moreover, it is suggested that future researchers also investigate other potential determinants of attitude toward digital piracy, such as past pirating behaviour (Cronan and AlRafee, 2008; Yoon, 2011); awareness of the law (Goles, et al., 2008); perceived certainty of punishment and perceived severity of punishment (Morton and Koufteros, 2008; Peace, Galletta and Thong, 2003); and software cost (Peace, Galletta and Thong, 2003). Another issue that needs further examination is the perceived overpricing of digital material. Cheng, Sims and Teegen (1997), for instance, found that the higher the software prices, the higher individual's desire to pirate the software. Thus, software, music, and other digital material manufacturers need to find ways to lower prices and make their products affordable to the population most likely to consume them. Lower prices may make potential and current pirates re-assess the real costs and benefits of pirating digital material (Cheng, Sims and Teegen, 1997). It is expected that consumers will switch to original products if they find that the prices are within their reach. 


\section{References}

Abhiseka, A. (2003). Indonesian Recording Industry at Crisis Point. Retrieved from http://www.thejakartapost.com/news/2003/03/17/indonesian-recording-industry-crisispoint.html

Ajzen, I. (2001). Nature and Operation of Attitudes. Annual Review of Psychology 52, 27 -58 .

Ajzen, I. (2005). Attitudes, Personality, and Behavior, $2^{\text {nd }}$ ed. Berkshire: Open University Press and McGraw-Hill, Inc.

Ajzen, I. and Fishbein, M. (1980). Understanding Attitudes and Predicting Social Behavior. Englewood Cliffs, N.J.: Prentice Hall, Inc.

Aleassa, H., Pearson, J.M., and McClurg, S. (2011). Investigating Software Piracy in Jordan: An Extension of the Theory of Reasoned Action. Journal of Business Ethics 98, 663-676.

Al-Rafee, S., and Cronan, T.P. (2006). Digital Piracy: Factors that Influence Attitude Toward Behavior. Journal of Business Ethics 63, 237-259.

Al-Rafee, S., and Dashti, A.E. (2012). A Cross Cultural Comparison of the Extended TPB: The Case of Digital Piracy. Journal of Global Information Technology Management 15(1), 524.

Ameen, E., Guffey, D. and McMillan, D. (1996). Gender Differences in Determining the Ethical Sensitivity of Future Professionals. Journal of Business Ethics 15, 591-597.

Asriani, T. (2011). Pirated E-books Up for Grab in Indonesia. Retrieved from http://www.thejakartapost.com/news/2011/10/17/pirated-e-books-grab-indonesia.html

Banerjee, D., Cronan, T.P., and Jones, T.W. (1998). Modeling IT Ethics: A Study in Situational Ethics”, MIS Quarterly 22(1), 31-60.

Bender, M.T., and Wang, Y. (2009). The Impact of Digital Piracy on Music Sales: A Cross -Country Analysis. International Social Science Review 84(3\&4), 157-170.

BeritaHukum.com. (2012). Piracy Rate di Indonesia Mencapai 86 Persen. Retrieved from http://beritahukum.com/detail_berita.php?judul=Piracy+Rate+di+Indonesia+Mencapai+86+P ersen\#.UH4fVm_MgcY.

Beu, D.S., Ronald, M.B. and Harvey, M.G. (2003). Ethical Decision-Making: A Multidimensional Construct. Business Ethics: A European Review 12(1), 88-197.

Bhattacharjee, S., Gopal, R.D., and Sanders, G.L. (2003). Digital Music and Online Sharing: Software Piracy 2.0? Communications of the ACM 46 (7), 107-111.

Blythe, J. (2008). Consumer Behaviour. London: Thomson Learning.

Bodur, H.D., Brinberg, D., and Coupey, E. (2000). Belief, Affect, and Attitude Alternative 
Models of the Determinants of Attitude. Journal of Consumer Psychology 9(1), 17-28.

Borkowski, S.C. and Ugras, Y. (1998). Business Students and Ethics: A Meta-Analysis. Journal of Business Ethics 17(11), 1117-1127.

BPS. (2011). Daerah Istimewa Yogyakarta Dalam Angka 2011. Yogyakarta: BPS Daerah Istimewa Yogyakarta.

Breckler, S. J., \& Wiggins, E. C. (1989). Affect versus Evaluation in the Structure of Attitudes. Journal of Experimental Social Psychology 25, 253-271.

BSA. (2011). Value of PC Software Theft in Indonesia Reaches Record High of US\$ 1.32 Billion. Retrieved from http://ww2.bsa.org/country/News\%20and\%20Events/News\%20Archives/global/05062011idc-globalpiracystudy.aspx

BSA (2012a). BSA Report Finds 59 Percent of Computer Users in Indonesia Admit They Pirate Software. Retrieved from http://global.bsa.org/globalpiracy2011/downloads/ press/pr_indonesia_en.pdf.

BSA (2012b). Shadow Market: 2011 BSA Global Software Piracy Study Ninth Edition, May. Retrieved from http://portal.bsa.org/globalpiracy2011/downloads/study_pdf/ 2011_BSA_Piracy_Study-Standard.pdf.

BSA (2012c). 2011 BSA Global Software Piracy Study: Indonesia. Retrieved from http://portal.bsa.org/globalpiracy2011/downloads/opinionsurvey/survey_indonesia.pdf.

Chang, M.K. (1998). Predicting Unethical Behavior: A Comparison of the Theory of Reasoned Action and the Theory of Planned Behavior. Journal of Business Ethics 17, 18251834.

Cheng, H.K., Sims, R.R., and Teegen, H. (1997). To Purchase or to Pirate Software: An Empirical Study. Journal of Management Information Systems 13(4), 49-60.

Christie, R., and Geis, F.L. (1970). Studies in Machiavellianism. New York, NY: Academic Press.

Cohen, J. R., Pant, L.W., and Sharp, D.J. (2001). An Examination of Differences in EthicalDecision Making Between Canadian Business Students and Accounting Professionals. Journal of Business Ethics 30(4), 319-336.

Cortese, A.J. (1989). The Interpersonal Approach to Morality: A Gender and Cultural Analysis. Journal of Social Psychology 129 (4), 429-442.

Cronan, T.P., and Al-Rafee, S. (2008). Factors that Influence the Intention Pirate Software and Media. Journal of Business Ethics 78, 527-545.

Dalton, D., and Ortegren, M. (2011). Gender Differences in Ethics Research: The Importance of Controlling for the Social Desirability Response Bias. Journal of Business Ethics 103, 7393. 
Dejean, S. (2009). What Can We Learn from Empirical Studies about Piracy? CESinfo Economic Studies 5 (2), 326-352.

Doyle, E., Hughes, J.F., and Summers, B. (2009). Research Methods in Taxation Ethics: Developing the Defining Issue Test (DIT) for a Tax-Specific Scenario. Journal of Business Ethics 88, 35-52.

Ergeneli, A., and Arikan, S. (2002). Gender Differences in Ethical Perceptions of Salespeople: An Empirical Examination in Turkey. Journal of Business Ethics 40(3), 247260.

Eri (2012). Generasi Penikmat Musik Gratisan. Kompas, 21 September, 36.

Fishbein, M., and Ajzen, I. (1975). Belief, Attitude, Intentions and Behavior: An Introduction to Theory and Research. Boston: Addison-Wesley.

Fit and Doe (2012). Cari Cara Melawan “Pencuri” Karya Kreatif”, Kompas 21 September, 34.

Fleischman, G., and Valentine, S. (2003). Professionals' Tax Liability and Ethical Evaluations in an Equitable Relief Innocent Spouse Case. Journal of Business Ethics 42(1), 27-44.

Ford, R. C., and Richardson, W. D. (1994). Ethical Decision Making: A Review of the Empirical Literature. Journal of Business Ethics 13, 205-221.

Franke, G. R., Crown, D. F., and Spake, D. F. (1997). Gender Differences in Ethical Perceptions of Business Practices: A Social Role Theory Perspective. Journal of Applied Psychology 82(6), 920-934.

Gan, L., and Koh, H. (2006). An Empirical Study of Software Piracy among Tertiary Institutions in Singapore. Information and Management 43, 640-649.

Goles, T., et al. (2008), Softlifting: Exploring Determinants of Attitude. Journal of Business Ethics 77, 481-499.

Gopal, R.D., and Sanders, G.L. (1997). Preventive and Deterrent Controls for Software Piracy. Journal of Management Information Systems 13 (4), 29-48.

Gopal, R.D., and Sanders, G.L. (1998). International Software Piracy: Analysis of Key Issues and Impacts. Information Systems Research 9 (4), 380-397.

Hartmaan, F.G.H., and Maas, V.S. (2010). Why Business Unit Controllers Create Budget Slack: Involvement in Management, Social Pressure, and Machiavellianism. Behavioral Research in Accounting 22(2), 27-49.

Hsieh, P.H., and Lee, T.K. (2012). Does Age Matter? Students' Perspectives of Unauthorized Software Copying under Legal and Ethical Considerations. Asia Pacific Management Review 17(4), 361-377. 
IIPA (2012). 2012 Special 301 Report on Copyright Protection and Enforcement: Indonesia. Retrieved from http://www.iipa.com/rbc/2012/2012SPEC301INDONESIA.PDF.

IIPA (2014). 2014 Special 301 Report on Copyright Protection and Enforcement. Retrieved from: http://www.iipa.com/pdf/2014SPEC301INDONESIA.pdf.

Ishida, C. (2006). How do Scores of DIT and MJT Differ? A Critical Assessment of the Use of Alternative Moral Development Scales in Studies of Business Ethics. Journal of Business Ethics 67, 63-74.

Jakarta Post (2010). RI Remains $12^{\text {th }}$ Worst Software Pirate on Weak Enforcement. Retrieved from http://www.thejakartapost.com/news/2010/05/12/ri-remains-12th-worst-software-pirateweak-enforcement.html

Kini, R.B., Rominger, A., and Vijayaraman, B.S. (2000). An Empirical Study of Software Piracy and Moral Intensity among University Students. Journal of Computer Information Systems 40(3), 62-72.

Kwong, K.K., Yau, O.H.M., Lee, J.S.Y., Sin, L.Y.M., and Tse, A.C.B. (2003). The Effects of Attitudinal and Demographic Factors on Intention to Buy Pirated CDs: The Case of Chinese Consumers. Journal of Business Ethics 47(3), 223-235.

Lee, K. (2009). Gender Differences in Hong Kong Adolescent Consumers’ Green Purchasing Behavior. Journal of Consumer Marketing 26(2), 87-96.

Levin, A.M., Dato-on, M.C., and Rhee, K. (2004). Money for Nothing and Hits for Free: the Ethics of Downloading Music from Peer-to-Peer Websites. Journal of Marketing Theory and Practice 12(1), 48-60.

Loe, T. W., Ferrell, L., and Mansfield, P. (2000). A Review of Empirical Studies Assessing Ethical Decision Making in Business. Journal of Business Ethics 25, 185-204.

Long, D. K. (1976). An Experimental Investigation of Selected Communication Effect of Machiavellianism. Speech Communication Association Convention.

Lysonski, S., and Durvasula, S. (2008). Digital Piracy of MP3s: Consumer and Ethical Predispositions. Journal of Consumer Marketing 25(3), 167-178.

Mason, E.S., and Mudrack, P.E. (1996). Gender and Ethical Orientation: A Test of Gender and Occupational Socialization Theories. Journal of Business Ethics 15(6), 599-604.

McCabe, A.C., Ingram, R., and Dato-on, M.C. (2006). The Business of Ethics and Gender. Journal of Business Ethics 64, 101-116.

McLaughin, B. (1970). Incidental Learning and Machiavellianism. Journal of Social Psychology 82, 109-115.

Moestafa, B.K. (2003). Indonesia’s Record Industry Dying as Piracy Gets Worse. Retrieved from http://www.thejakartapost.com/news/2003/02/03/indonesia039s-record-industry-dyingpiracy-gets-worse.html 
Moores, T.T., and Chang, J.C-J. (2006). Ethical Decision Making in Software Piracy: Initial Development and Test of a Four-Component Model. MIS Quarterly 30(1), 167-180.

Moores, T.T., and Esichaikul, V. (2011). Socialization and Software Piracy: A Study. Journal of Computer Information Systems Spring, 1-9.

Morton, N.A. and Koufteros, X. (2008). Intention to Commit Online Music Piracy and Its Antecedents: An Empirical Investigation. Structural Equation Modelling 15, 491-512.

Nunnally, J.C. (1978). Psychometric Theory, Second Edition. New York: McGraw-Hill, Inc.

O'Fallon, M.J., and Butterfield, K.D. (2005). A Review of the Empirical Ethical DecisionMaking Literature: 1996-2003. Journal of Business Ethics 59, 375-413.

Odell, P.M., Korgen, K.D., Schumacher, P., and Delucchi, M. (2000). Internet Use Among Female and Male College Students. Cyber Psychology \& Behavior 3(5), 855-862.

Paradice, D.B., and Dejoie, R.M. (1991). The Ethical Decision-Making Processes of Information Systems Workers. Journal of Business Ethics 10, 1-21.

Peace, A.G., Galletta, D.F., and Thong, J.Y.L. (2003). Software Piracy in the Workplace: A Model and Empirical Test. Journal of Management Information System 20(1), 153-177.

Penz, E., and Stöttinger, B. (2005). Forget the 'Real' Thing-Take the Copy! An Explanatory Model for the Volitional Purchase of Counterfeit Products. Advances in Consumer Research 32, 568-575.

Purwanto, D. (2012). Kominfo Blokir 20 Situs “Download” Musik Ilegal. Retrieved from http://tekno.kompas.com/read/2012/05/16/0915566/Kominfo.Blokir.20.Situs.Download.Musi k.Ilegal.

Rest, J. (1986). DIT Manual: Manual for the Defining Issue Test, Third Edition, Center for the Study of Ethical Development, Minneapolis, Minnesota.

Riemenschneider, C.K., Leonard, L.N.K., and Manly, T.S. (2012). Students' Ethical Decision-Making in an Information Technology Context: A Theory of Planned Behavior Approach”, Journal of Information Systems Education 22(3), 203-214.

Robertson, K., McNeill, L., Green, J., and Roberts, C. (2012). Illegal Downloading, Ethical Concern, and Illegal Behavior. Journal of Business Ethics 108, 215-227.

Robin, D. and Reidenbach, R. (1996). The Perceived Importance of Ethical Issues as an Influence on the Ethical Decision-Making of Ad Managers. Journal of Business Research 35, 17-28.

Robin, D., and Babin, L. (1997). Making Sense of the Research on Gender and Ethics in Business: A Critical Analysis and Extension. Business Ethics Quarterly 7, 61-90. 
Roxas, M. L., and Stoneback, J.Y. (2004). The Importance of Gender Across Cultures in Ethical Decision-Making. Journal of Business Ethics 50, 149-165.

Ruegger, D. and King, E. W. (1992). A Study of the Effect of Age and Gender upon Student Business Ethics. Journal of Business Ethics 11, 179-86.

Schepers, D.H. (2003). Machiavellianism, Profit, and the Dimensions of Ethical Judgment: A Study of Impact. Journal of Business Ethics 42, 339-352.

Shoham, A., Ruvio, A., and Davidow, M. (2008). (Un)ethical Consumer Behavior: Robin Hoods or Plain Hoods?” Journal of Consumer Marketing 25(4), 200-210.

Sidani, Y, Zbib, I, Rawwas, M., and Mousawwer, T. (2009). Gender, Age, and Ethical Sensitivity: The Case of Lebanese Workers. Gender in Management: An International Journal 24 (3), 211-227.

Singhapakdi, A., Gopinath, M., Marta, J.K. and Carter, L.L. (2007). Antecedents and Consequences of Perceived Importance of Ethics in Marketing Situations: A Study of Thai Businesspeople. Journal of Business Ethics 81, 887-904.

Singhapakdi, A., Vitell, S.J. and G. R. Franke, G.R. (1999). Antecedents, Consequences and Mediating Effects of Perceived Moral Intensity and Personal Moral Philosophies. Journal of the Academy of Marketing Science 27(1), 19-36.

Sinha, R.K., and Mandel, N. (2008). Preventing Digital Music Piracy: The Carrot or the Stick?. Journal of Marketing 72, 1-15.

Sundararajan, A. (2004). Managing Digital Piracy: Pricing and Protection. Information Systems Research 15(3), pp. 287-308.

Trafimow, D. and Sheeran, P. (1998). Some Tests of the Distinction between Cognitive and Affective Beliefs. Journal of Experimental Social Psychology 34, 378-397.

USTR. (2014). 2014 Special 301 Report. Retrieved from http://www.ustr.gov/sites/default/files/USTR\%202014\%20Special\%20301\%20Report\%20to \%20Congress\%20FINAL.pdf

Vitell, S.J., Rallpalli, K. and Singhapakdi, A. (1993). Marketing Norms: The Influence of Personal Moral Philosophies and Organizational Ethical Culture. Journal of the Academy of Marketing Science 21(Fall), 331-337.

Wade, J. (2004).The Music Industry’s War on Piracy. Risk Management Magazine February, pp. 10-15.

Wagner, S., and Sanders, G. (2001). Considerations in Ethical Decision-Making and Software Piracy. Journal of Business Ethics 29 (1/2), 161-167.

Wakefield, R.L. (2008). Accounting and Machiavellianism. Behavioral Research in Accounting 20(1), 115-129. 
Wang, F., Zhang, H., Zang, H., and Ouyang, M. (2005). Purchasing Pirated Software: An Initial Examination of Chinese Consumers. Journal of Consumer Marketing 22(6), 340-351.

Wastell, C., and Booth, A. (2003). Machiavellianism: An Alexitymic Perspective. Journal of Social and Clinical Psychology 22(6), 730-744.

Yoon, C. (2011). Theory of Planned Behavior and Ethics Theory in Digital Piracy: An Integrated Model. Journal of Business Ethics 100, 405-417. 


\section{Appendices}

Figure 1. Research Framework

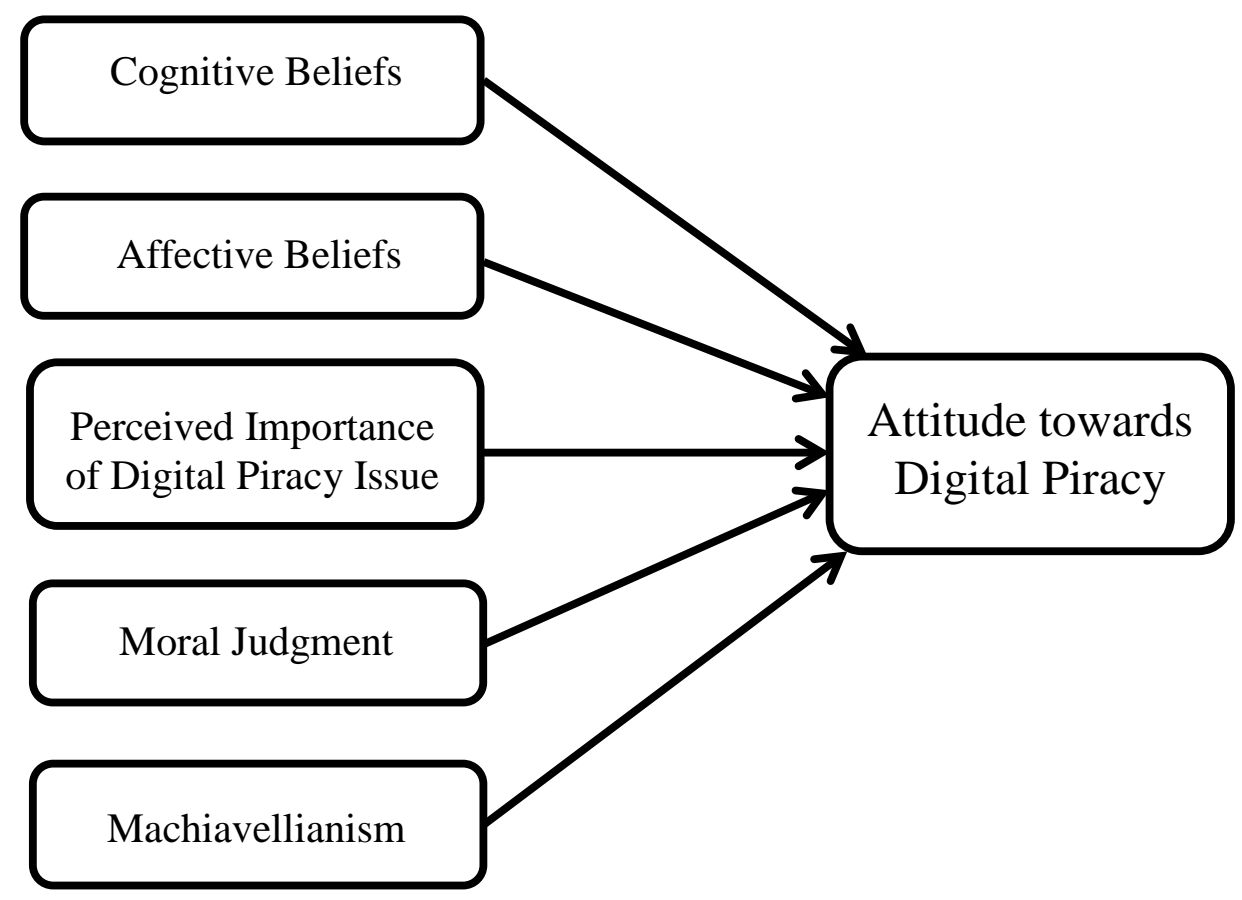

Source: Adapted from Al-Rafee and Cronan (2006). 


\begin{tabular}{|c|c|c|}
\hline No. & Ethical Dilemma Story & Questions \\
\hline 1. & $\begin{array}{l}\text { Escaped Prisoner } \\
\text { A man had been sentenced to prison } \\
\text { for } 10 \text { years. After one year, } \\
\text { however, he escaped from prison, } \\
\text { moved to a new area of the country, } \\
\text { and took on the name of Sule. For } 8 \\
\text { years he worked hard, and gradually } \\
\text { he saved enough money to buy his } \\
\text { own business. He was fair to his } \\
\text { customers, gave his employees top } \\
\text { wages, and gave most of his own } \\
\text { profits to charity. Then one day, } \\
\text { Jupe, an old neighbour, recognized } \\
\text { him as the man who escaped from } \\
\text { prison } 8 \text { years before and whom the } \\
\text { police had been looking for. }\end{array}$ & 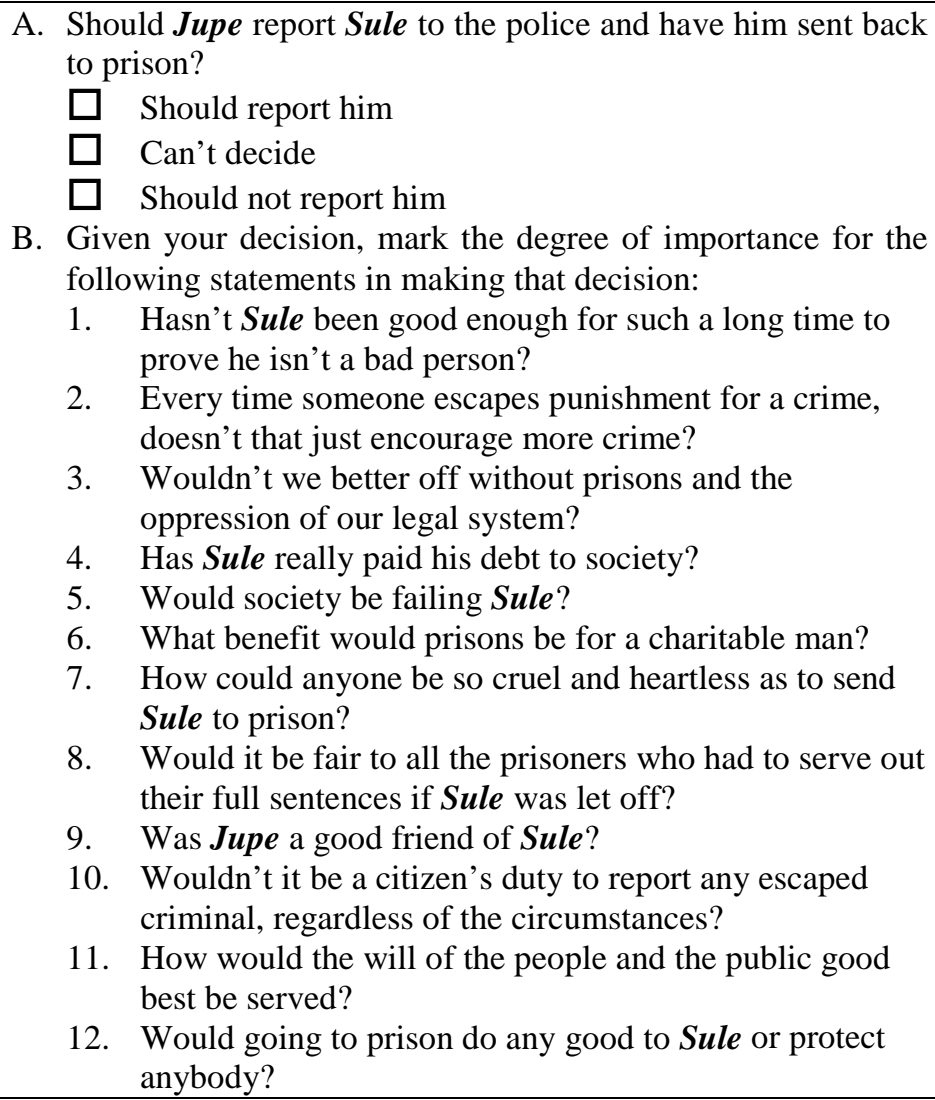 \\
\hline 2. & $\begin{array}{l}\text { Tukul and the Drug } \\
\text { In Europe, a woman was near death } \\
\text { from a special kind of cancer. There } \\
\text { was one drug that doctors thought } \\
\text { might save her. It was a form of } \\
\text { radium that a druggist in the same } \\
\text { town has recently discovered. The } \\
\text { drug was expensive to make, but the } \\
\text { druggist was charging ten times what } \\
\text { the drug cost to make. He paid } \$ 200 \\
\text { for the radium and charged } \$ 2000 \text { for } \\
\text { a small dose of the drug. The sick } \\
\text { women's husband, Tukul, went to } \\
\text { everyone he knew to borrow the } \\
\text { money, but he could only get together } \\
\text { about \$1000, which is half of what it } \\
\text { cost. He told the druggist that his } \\
\text { wife was dying and asked him to sell } \\
\text { it cheaper or let him pay later. But the } \\
\text { druggist said, ' No, I discovered the } \\
\text { drug and I'm going to make money } \\
\text { from it."' So Tukul got desperate and } \\
\text { began to think about breaking into the } \\
\text { man's store to steal the drug for his } \\
\text { wife. }\end{array}$ & $\begin{array}{l}\text { A. Should Tukul steal the drug? } \\
\square \quad \text { Should steal it } \\
\square \quad \text { Can't decide } \\
\square \text { Should not steal it } \\
\text { B. Given your decision, mark the degree of importance for the } \\
\text { following statements in making that decision: } \\
\text { 1. Whether a community's laws are going to be upheld. } \\
\text { 2. Isn't it only natural for a loving husband to care so } \\
\text { much for his wife that he'd steal? } \\
\text { 3. Is Tukul willing to risk being beaten by masses or } \\
\text { caught by the police for the chance that stealing the drug } \\
\text { might help his wife? } \\
\text { 4. Whether Tukul is a professional wrestler, or has } \\
\text { considerable influence with professional wrestlers } \\
\text { 5. Whether Tukul is stealing for himself or doing this } \\
\text { solely to help someone else. } \\
\text { 6. Whether the pharmacist's rights to his invention have to } \\
\text { be respected. } \\
\text { 7. Whether the essence of living is more encompassing } \\
\text { than the termination of dying, socially and individually. } \\
\text { 8. What values are going to be the basis for governing how } \\
\text { 9. Weople act towards each other? } \\
\text { Whether the pharmacist is going to be allowed to hide } \\
\text { 11. Wehind a worthless law which only protects the rich } \\
\text { anyway. } \\
\text { Whether the law in this case is getting in the way of the } \\
\text { so greedy and cruel. }\end{array}$ \\
\hline
\end{tabular}




\begin{tabular}{|c|c|c|}
\hline No. & Ethical Dilemma Story & Questions \\
\hline & & $\begin{array}{l}\text { 12. Would stealing in such a case bring about more total } \\
\text { good for the whole society or not? }\end{array}$ \\
\hline 3. & $\begin{array}{l}\text { The Doctor's Dilemma } \\
\text { A lady was dying of cancer which } \\
\text { could not be cured and she had only } \\
\text { about six months to live. She was in } \\
\text { terrible pain, but she was so weak } \\
\text { that a good dose of pain-killer like } \\
\text { morphine would make her die sooner. } \\
\text { She was delirious and almost crazy } \\
\text { with pain, and in her calm periods, } \\
\text { she would ask the doctor to give her } \\
\text { enough morphine to kill her. She said } \\
\text { she couldn't stand the pain and that } \\
\text { she was going to die in a few months } \\
\text { anyway. }\end{array}$ & 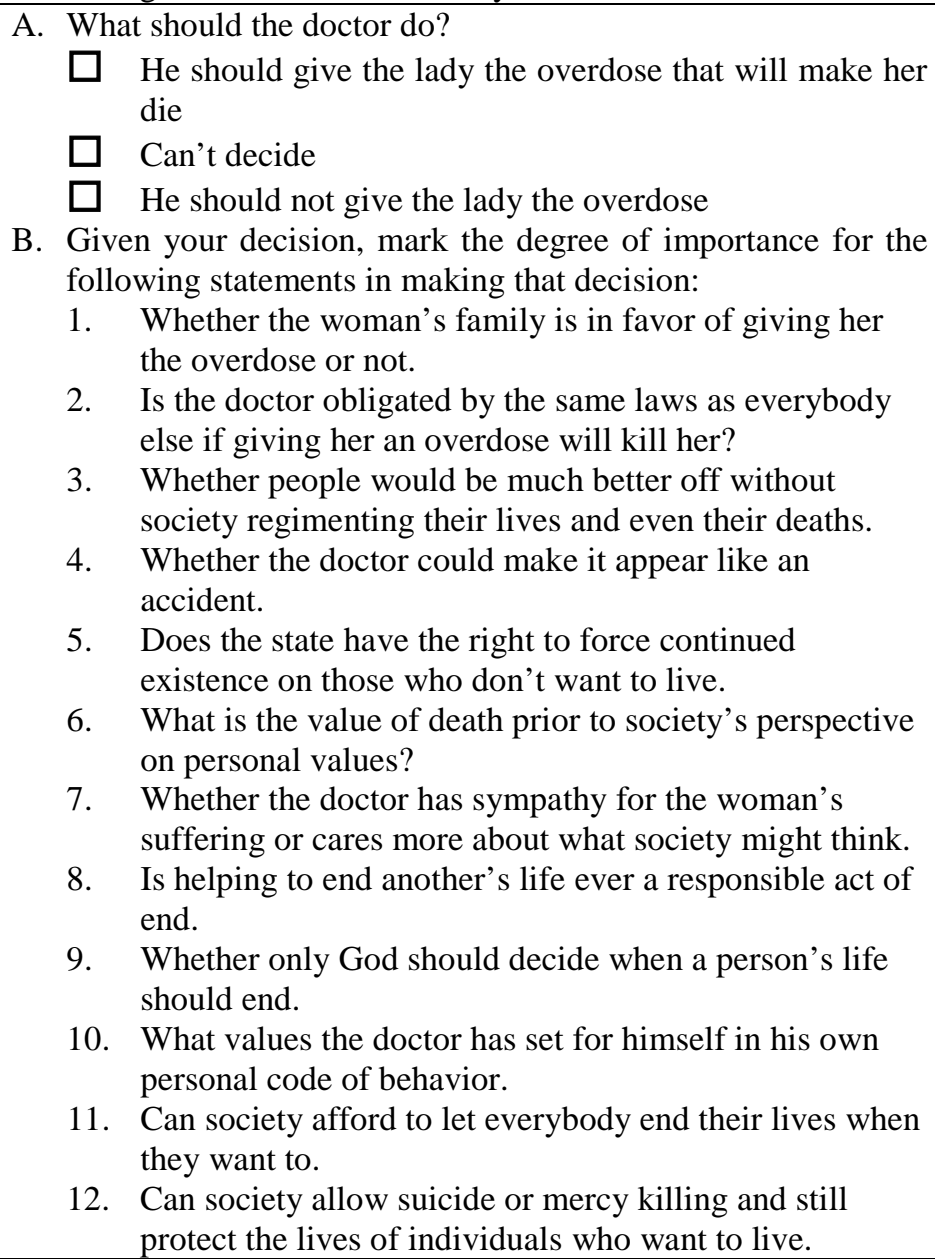 \\
\hline
\end{tabular}


Table 2. Profiles of Respondents

\begin{tabular}{|c|c|c|}
\hline Description & $\begin{array}{c}\text { Number of } \\
\text { Respondents }\end{array}$ & Percentage (\%) \\
\hline $\begin{array}{l}\text { Age } \\
<18 \text { years old } \\
18-20 \text { years old } \\
21-23 \text { years old } \\
24-26 \text { years old } \\
>26 \text { years old } \\
\end{array}$ & $\begin{array}{c}10 \\
111 \\
87 \\
11 \\
4 \\
\end{array}$ & $\begin{array}{c}4.5 \\
49.8 \\
39.0 \\
4.9 \\
1.8 \\
\end{array}$ \\
\hline $\begin{array}{l}\text { Gender } \\
\text { Male } \\
\text { Female }\end{array}$ & $\begin{array}{c}76 \\
147\end{array}$ & $\begin{array}{l}34.1 \\
65.9\end{array}$ \\
\hline $\begin{array}{l}\text { Status } \\
\text { Married } \\
\text { Single }\end{array}$ & $\begin{array}{c}6 \\
217\end{array}$ & $\begin{array}{c}2.7 \\
97.3\end{array}$ \\
\hline $\begin{array}{l}\text { Current Education Level } \\
\text { Diploma }\left(\mathrm{D}_{3}\right) \\
\text { Undergraduate }\left(\mathrm{S}_{1}\right) \\
\text { Post-graduate }\left(\mathrm{S}_{2} \text { or } \mathrm{S}_{3}\right) \\
\text { Others (Diploma } 1 \text { or Diploma 2) }\end{array}$ & $\begin{array}{c}5 \\
210 \\
3 \\
5\end{array}$ & $\begin{array}{c}2.2 \\
94.2 \\
1.3 \\
2.2\end{array}$ \\
\hline $\begin{array}{l}\text { Study Field } \\
\text { Management } \\
\text { Accounting } \\
\text { Information Technology } \\
\text { Communication } \\
\text { Others }\end{array}$ & $\begin{array}{l}72 \\
36 \\
12 \\
12 \\
91\end{array}$ & $\begin{array}{c}32.3 \\
16.1 \\
5.4 \\
5.4 \\
39.7 \\
\end{array}$ \\
\hline
\end{tabular}

Note: $\mathrm{n}=223$. 
Table 3. Reliability and Correlation Results

\begin{tabular}{|l|c|c|c|c|c|c|}
\hline \multicolumn{1}{|c|}{ Construct } & $\mathbf{1}$ & $\mathbf{2}$ & $\mathbf{3}$ & $\mathbf{4}$ & $\mathbf{5}$ & $\mathbf{6}$ \\
\hline $\begin{array}{l}\text { 1. Attitude towards } \\
\text { digital piracy }\end{array}$ & 1 & & & & & \\
\hline 2. Moral judgment & -0.092 & 1 & & & & \\
\hline 3. Machiavellianism & $0.353^{* * *}$ & -0.080 & 1 & & & \\
\hline 4. Cognitive beliefs & $-0.340^{* * *}$ & 0.052 & $-0.191^{* * *}$ & 1 & & \\
\hline 5. Affective beliefs & $0.581^{* * *}$ & -0.006 & $0.340^{* * *}$ & $-0.475^{* * *}$ & 1 & \\
\hline 6. Perceived importance & $-0.513^{* * *}$ & 0.106 & $-0.278^{* * *}$ & $0.321^{* * *}$ & $-0.525^{* * *}$ & 1 \\
\hline Number of items & 4 & 50 & 13 & 4 & 9 & 4 \\
\hline Cronbach $\alpha$ & 0.830 & $\mathrm{n} / \mathrm{a}^{*}$ & 0.698 & 0.751 & 0.935 & 0.901 \\
\hline
\end{tabular}

Notes: $* * *$ Significant at $\alpha=1 \% ; \mathrm{n}=223$.

Moral judgment was measured using P-score index. 
Table 4. Comparison Between Female and Male Samples

\begin{tabular}{|c|c|c|c|c|c|c|}
\hline \multirow{2}{*}{ Variable } & \multicolumn{2}{|c|}{ Female } & \multicolumn{2}{c|}{ Male } & \multicolumn{2}{c|}{ t-test } \\
\cline { 2 - 7 } & Mean & $\begin{array}{c}\text { Std. } \\
\text { Dev. }\end{array}$ & Mean & $\begin{array}{c}\text { Std. } \\
\text { Dev. }\end{array}$ & t & Sig. \\
\hline \hline $\begin{array}{c}\text { Attitude towards Digital } \\
\text { Piracy }\end{array}$ & 3.230 & 1.450 & 3.678 & 1.337 & -2.245 & $0.026^{* *}$ \\
\hline $\begin{array}{c}\text { Cognitive Beliefs } \\
\text { Affective Beliefs }\end{array}$ & 11.563 & 8.970 & 9.283 & 7.675 & 1.887 & 0.060 \\
\hline Perceived Importance & 4.702 & 1.439 & 3.934 & 1.372 & -3.127 & $0.002^{* * *}$ \\
\hline Moral Judgment (P-score) & 25.125 & 12.935 & 4.319 & 1.510 & 1.857 & 0.065 \\
\hline Machiavellianism & 2.918 & 0.680 & 23.026 & 12.918 & 1.149 & 0.252 \\
\hline
\end{tabular}

Notes: ** significant at $\rho \leq 0.05 ; * * *$ significant at $\rho \leq 0.01$. 
Table 5. Summary of OLS (Ordinary Least Squares) Regression Models

\begin{tabular}{|c|c|c|c|c|c|c|}
\hline \multirow{2}{*}{ Independent Variable } & \multirow{2}{*}{$\begin{array}{l}\text { Standardized } \\
\beta \text { Coefficient }\end{array}$} & \multicolumn{2}{|c|}{ t-test } & \multicolumn{2}{|c|}{ F-test } & \multirow{2}{*}{ Adj. $R^{2}$} \\
\hline & & $\mathbf{t}$ & Sig. & $\bar{F}$ & Sig. & \\
\hline \multicolumn{7}{|c|}{ FEMALE SAMPLE } \\
\hline Cognitive Beliefs & -0.010 & -0.136 & 0.892 & \multirow{5}{*}{17.724} & \multirow{5}{*}{$0.000 * * *$} & \multirow{5}{*}{0.364} \\
\hline Affective Beliefs & 0.361 & 4.124 & $0.000 * * *$ & & & \\
\hline Perceived Importance & -0.269 & -3.318 & $0.001 * * *$ & & & \\
\hline $\begin{array}{l}\text { Moral Judgment (P- } \\
\text { score) }\end{array}$ & 0.035 & 0.526 & 0.600 & & & \\
\hline Machiavellianism & 0.140 & 2.027 & $0.045^{* *}$ & & & \\
\hline \multicolumn{7}{|c|}{ MALE SAMPLE } \\
\hline Cognitive Beliefs & -0.118 & -1.234 & 0.221 & \multirow{5}{*}{14.589} & \multirow{5}{*}{$0.000 * * *$} & \multirow{5}{*}{0.475} \\
\hline Affective Beliefs & 0.368 & 3.458 & $0.001^{* * *}$ & & & \\
\hline Perceived Importance & -0.225 & -2.362 & $0.021 * *$ & & & \\
\hline $\begin{array}{l}\text { Moral Judgment (P- } \\
\text { score) }\end{array}$ & -0.223 & -2.546 & $0.013^{* *}$ & & & \\
\hline Machiavellianism & 0.127 & 1.322 & 0.190 & & & \\
\hline
\end{tabular}

Notes: Dependent Variable $=$ Attitude towards digital piracy.

$* *$ significant at $\rho \leq 0.05$; *** significant at $\rho \leq 0.01$. 